\title{
THE ASSESSMENT OF WATER SANITARY QUALITY AND THE PRESENCE OF DRUG-RESISTANT Escherichia coli STRAINS IN WATERS USED FOR RECREATION IN LESSER POLAND
}

\section{OCENA STANU SANITARNEGO I OBECNOŚĆ LEKOOPORNYCH SZCZEPÓW Escherichia coli W WODACH MAŁOPOLSKI UŻYTKOWANYCH REKREACYJNIE}

\author{
Department of Microbiology, University of Agriculture, Kraków, Poland
}

\begin{abstract}
Streszczenie. Drobnoustroje lekooporne to obecnie nie tylko problem kliniczny, ponieważ coraz częściej podczas analiz mikrobiologicznych materiału środowiskowego (wody i gleby) izolowane są bakterie odporne na powszechnie stosowane w terapii antybiotyki, co może stanowić znaczne zagrożenie dla zdrowia. Celem niniejszych badań była ocena stanu sanitarnego wody i częstotliwości występowanie szczepów Escherichia coli opornych na antybiotyki. Przeprowadzono badania w 10 punktach pomiarowych zlokalizowanych na rzece Dunajec oraz w zbiornikach wodnych na terenie Krakowa i Kryspinowa wykorzystywanych do celów rekreacyjnych. $\mathrm{Na}$ potrzeby oceny liczebności bakterii $E$. coli pobrane próbki wody zostały poddane analizie metodą filtracji membranowej. Lekooporność badano z wykorzystaniem metody dyfuzyjno-krążkowej, ponadto zbadano występowanie mechanizmu ESBL zgodnie z zaleceniami KORLD i EUCAST. Na podstawie uzyskanych wyników stwierdzono, że w dwóch punktach pomiarowych zlokalizowanych na rzece Biały Dunajec liczebność E. coli przekraczała normy dopuszczalne dla kąpielisk. Oporne szczepy izolowano głównie z kąpieliska w Kryspinowie - Na Piaskach, ale były one również obecne w wodach Dunajca. Zaobserwowano głównie oporność na jeden z testowanych antybiotyków; nie stwierdzono obecności wielolekoopornych bakterii. Najczęściej izolaty były oporne na tykarcylinę, sulfametoksazol/trimetoprim i tetracyklinę. Wszystkie testowane szczepy były ESBL negatywne.
\end{abstract}

Key words: water, Escherichia coli, water, drug resistance, ESBL.

Słowa kluczowe: Escherichia coli, woda, lekooporność, ESBL.

\section{INTRODUCTION}

Poland is ranked among the countries which have poor water resources. The annual resource water is only about $1600 \mathrm{~m}^{3}$ per capita. An entirely different situation is in the other European countries, where resources are estimated at approximately $4600 \mathrm{~m}^{3}$ per year (Gutry-Korycka et al. 2014). Water resources in Poland are characterized by significant seasonal variations and uneven geographical distribution. Poland also does not have sufficient protection from intermittent excesses or deficits of water (Mały Rocznik Statystyczny 2015). Taking into account such small domestic water resources, it becomes highly important to control both - the chemical and microbiological quality.

Corresponding author - Adres do korespondencji: Maria J. Chmiel, Department of Microbiology, University of Agriculture, Adama Mickiewicza 24/28, 30-059 Kraków, Poland, e-mail: maria.chmiel@ur.krakow.pl 
Examination of the sanitary condition of water (based on bacteriological indicators) is constant monitoring of sources (surface water reservoirs, water catchment areas, boreholes, wells) and devices which treat and distribute water (Libudzisz and Kowal 2000).

The presence of fecal coliforms is an essential parameter in the water quality assessment (Rompré et al. 2002; Grisey et al. 2010), moreover, this group is increasingly used also as an indicator of the state of the soil environment (Topp et al. 2003; Estrada et al. 2004; Brochier et al. 2012).

Enterobacteriaceae are a large group of closely related bacteria most often used as indicators of the poor sanitary state not only in the environment evaluation. Most bacteria of this family are opportunistic pathogens, or conditionally pathogenic microorganisms mainly colonizing the intestines of humans and animals. Most of them grow on conventional microbiological media in a wide range of temperatures and $\mathrm{pH}$, and so are well suited to the role of indicators of sanitary conditions (Rompré et al. 2002; Stevens et al. 2003; Jarząb et al. 2011).

Among frequently caused by the Enterobacteriaceae there are urinary and respiratory tract infections, infections of wounds, skin and sepsis. Their pathogenesis is often related to their relocation from the place the physiological existence to other places where they have good conditions for their growth and development. Bacteria Enterobacteriaceae exhibited specific resistance to many antibacterial agents. This is related to their heightened genetic variability (Kayser et al. 2007).

The most sensitive indicator of bacteriological contamination of water is the presence of Escherichia coli because its occurrence in water intended for drinking, bathing and food industry indicates fecal contamination of water and a potential epidemiological threat.

Increasingly, attention is paid to occurrence, in the environment outside hospitals, of microorganisms characterized by resistance to many antibiotics used in the routine treatment of infections of various origin. The presence of antibiotic-resistant strains of $E$. coli in bathing water can be a significant health problem, even if their number does not exceed standards.

Bacteria that are resistant to antibiotics have different specific resistance mechanisms such as: the inactivation of antibiotics, the replacement of the target by a new molecule that has no affinity to the drug, structural changes in the site of drug action, getting rid of the drug from the cell by the actively pumping it out, reducing the ability of the antibiotic to penetrate the cell membranes (Nikonorow et al. 2013; Oliphant and Eroschenko 2015).

However, one of the most important and increasingly dangerous resistance mechanisms of bacteria is the production of $\beta$-lactamases. There are specific enzymes that hydrolyze the $\beta$-lactame ring. Another mechanism is related to proteins which bind penicillin (PBP) $\beta$-lactams inhibit the growth of bacteria as they permanently bind the proteins and thus inhibit their enzymatic activity. Bacterial resistance can also be determined by the mechanisms which have the ability to limit the penetration of bacterial cells by $\beta$-lactams. In Enterobacteriaceae is observed one of the most important epidemiologically resistant mechanism - it is the production by these bacteria of $\beta$-lactamases with extended spectrum (ESBL) (Gniadkowski 2008; Martinez-Martinez 2008).

ESBL enzymes were identified for the first time in 1983 (Knothe et al. 1983). These enzymes cause the hydrolysis of penicillins, aztreonam and some cephalosporins. Strains which exhibit ESBL are more dangerous since, despite the fact that their growth is inhibited 
eg. by clavulanic acid, sulbactam and tazobactam (which are $\beta$-lactamase inhibitors), they increasingly exhibit resistance to $\beta$-lactams combined with inhibitors (Gniadkowski et al. 2009; Oliphant and Eroschenko 2015).

Considering the growing threat arising from the presence of multidrug resistant bacteria in the surface waters, the aim of this study was the assessment of water sanitary state and the occurrence of drug resistant strains of Escherichia coli in ten sampling points located on selected water reservoirs used for recreation on the Dunajec river and reservoirs in Kraków area and Kryspinów.

\section{MATERIAL AND METHODS}

Water samples for microbiological examination were collected in 10 sampling points located on selected water reservoirs used for recreation on the Dunajec river (the river is a tourist attraction, a popular site for fishing, kayaking and rafting, there are also numerous bathing areas), and reservoirs in Kraków area and Kryspinów (bathing areas).

Samples were collected 19th April 2015 from ten locations (Table 1) - five points on the river Dunajec (Czarny Dunajec in Witów and Ludźmierz, Biały Dunajec in Poronin and Szaflary, Dunajec in Krościenko) three recreational areas in Kraków (Przylasek Rusiecki, Bagry, Zakrzówek) and two in Kryspinów (reservoir in Piaski and Budzyński) as recommended by standards (PN-EN ISO 19458 : 2007; Rozporządzenie Ministra Zdrowia z dnia 8 kwietnia 2011 r.).

Microbiological analysis was carried out by the membrane filtration method (PN-EN ISO 9308-1 : 2014-12) on agar TBX Agar (Tryptone Bile Agar with X-Glucuronide, a chromogenic medium for the detection of $E$. coli) (Biocorp). After 24 hours of incubation in $44^{\circ} \mathrm{C}$ colonies of coliforms on membranes were counted. After the incubation the pure cultures of Escherichia coli were isolated on the chromogenic TBX medium (BTL) and than their taxonomic position was confirmed.

The study of drug resistance of randomly selected strains was performed by the disc diffusion method according to the recommendation of KORLD (National Reference Center for Microorganisms Susceptibility Testing) and EUCAST (The European Committee on Antimicrobial Susceptibility Testing) on Mueller-Hinton (Biocorp) medium (Kayser et al. 2007; Gniadkowski et al. 2009; Breakpoints tables... 2015).

Primary antibiogram for 41 strains was made using the following antibiotics: amoxicillin/ /clavulanic acid AMC (20/10), ampicillin AM (10 $\mu$ g), cephalothin CF $(30 \mu \mathrm{g})$, cephazolin CZ $(30 \mu \mathrm{g})$, cefamandole MA $(30 \mu \mathrm{g})$, cefuroxime CXM $(30 \mu \mathrm{g})$, fosfomycin + glucose-6-phosphate FOS $(200 \mu \mathrm{g})$, gentamicin GM $(10 \mu \mathrm{g})$, nitrofurantoin F/M $(300 \mu \mathrm{g})$, norfloxacin NOR $(10 \mu \mathrm{g})$, ofloxacin OFX (5 $\mu \mathrm{g})$, sulfamethoxazole/trimethoprim SXT $(23,75 \mu \mathrm{g} / 1,25 \mu \mathrm{g})$, tetracycline TE $(10 \mu \mathrm{g})$ as well as expanded antibiogram using: amikacin AN (30 $\mu \mathrm{g})$ aztreonam ATM $(30 \mu \mathrm{g})$, cefepime FEP $(30 \mu \mathrm{g})$, cefotaxime CTX $(30 \mu \mathrm{g})$, ceftazidime CAZ $(30 \mu \mathrm{g})$, imipenem IPM $(10 \mu \mathrm{g})$, meropenem MEM $(10 \mu \mathrm{g})$, ticarcillin TIC (75 $\mu \mathrm{g})$. Evaluation of susceptibility was based on the size of inhibition zone acording to the EUCAST guidelines (Breakpoints tables... 2015).

ESBLs were determined by two discs with ceftazidime CAZ $(30 \mu \mathrm{g})$ and cefotaxime CTX $(30 \mu \mathrm{g})$ placed in a distance of $2 \mathrm{~cm}$ (between centers) from the disc with amoxicillin/ /clavulanic acid AMC (20/10) - Gniadkowski et al. (2009). 


\section{RESULTS AND DISCUSSION}

The tested waters differed in temperature. The temperature of the Dunajec increased with distance from the source, however, did not exceeded $7^{\circ} \mathrm{C}$ (Table 1), which is typical for cold waters of mountain rivers. The temperature of reservoirs in Kraków and Kryspinów oscillated around $10^{\circ} \mathrm{C}$. Low temperatures do not create favorable conditions for the growth and development of microorganisms in water, but the time of survival of $E$. coli in low temperatures can extend (Van Elsas et al. 2011), posing a greater threat to users of reservoirs and watercourses.

Table 1. Sampling points location and water and air temperature during sampling Tabela 1. Lokalizacja punktów badawczych oraz temperatura wody i powietrza w czasie poboru próbek

\begin{tabular}{llccc}
\hline $\begin{array}{l}\text { Sampling point } \\
\text { Punkt pobrania }\end{array}$ & $\begin{array}{c}\text { Longitude } \\
\text { Długość } \\
\text { geograficzna }\end{array}$ & $\begin{array}{c}\text { Latitude } \\
\text { Szerokość } \\
\text { geograficzna }\end{array}$ & $\begin{array}{c}\text { Temperature } \\
\text { of water } \\
\text { Temperatura } \\
\left.\text { wody [ }{ }^{\circ} \mathrm{C}\right]\end{array}$ & $\begin{array}{c}\text { Temperature } \\
\text { of air } \\
\text { Temperatura } \\
\left.\text { powietrza [ }{ }^{\circ} \mathrm{C}\right]\end{array}$ \\
\hline 1. Czarny Dunajec - Witów & $019^{\circ} 51^{\prime} 05.9^{\prime \prime} \mathrm{E}$ & $49^{\circ} 17^{\prime} 30.5^{\prime \prime} \mathrm{N}$ & 5.0 & 2.0 \\
\hline 2. Czarny Dunajec - Ludźmierz & $019^{\circ} 58^{\prime} 54.8^{\prime \prime} \mathrm{E}$ & $49^{\circ} 27^{\prime} 52.1^{\prime \prime} \mathrm{N}$ & 6.1 & 3.0 \\
\hline 3. Biały Dunajec - Poronin & $020^{\circ} 00^{\prime} 06.7^{\prime \prime} \mathrm{E}$ & $49^{\circ} 20^{\prime} 19.2^{\prime \prime} \mathrm{N}$ & 4.9 & 2.0 \\
\hline 4. Biały Dunajec - Szaflary & $020^{\circ} 01^{\prime} 37.1^{\prime \prime} \mathrm{E}$ & $49^{\circ} 25^{\prime} 35.6^{\prime \prime} \mathrm{N}$ & 5.3 & 3.0 \\
\hline 5. Dunajec - Krościenko & $020^{\circ} 25^{\prime} 31.6 " \mathrm{E}$ & $49^{\circ} 26^{\prime} 41.4^{\prime \prime} \mathrm{N}$ & 7.0 & 8.0 \\
\hline 6. Kraków - Przylasek Rusiecki & $020^{\circ} 09^{\prime} 36.8^{\prime \prime} \mathrm{E}$ & $50^{\circ} 02^{\prime} 54.5^{\prime \prime} \mathrm{N}$ & 11.7 & 9.4 \\
\hline 7. Kraków - Bagry & $019^{\circ} 59^{\prime} 36.6 \mathrm{E}$ & $50^{\circ} 02^{\prime} 00.1^{\prime \prime} \mathrm{N}$ & 10.5 & 9.5 \\
\hline 8. Kraków - Zakrzówek & $019^{\circ} 54^{\prime} 44.4^{\prime \prime} \mathrm{E}$ & $50^{\circ} 02^{\prime} 04.5^{\prime \prime} \mathrm{N}$ & 9.6 & 9.4 \\
\hline 9. Kryspinów - Na Piaskach & $019^{\circ} 47^{\prime} 44.7^{\prime \prime} \mathrm{E}$ & $50^{\circ} 02^{\prime} 53.5^{\prime \prime} \mathrm{N}$ & 11.0 & 8.1 \\
\hline 10. Kryspinów - Reservoir Budzyński & $019^{\circ} 47^{\prime} 13.9^{\prime \prime} \mathrm{E}$ & $50^{\circ} 03^{\prime} 01.4^{\prime \prime} \mathrm{N}$ & 10.0 & 8.1 \\
\hline
\end{tabular}

The most polluted, and thus not meeting the criteria of microbiological contamination for water intended for recreational purposes, were the Biały Dunajec waters (Table 2) in sampling points located both in Poronin and in Szaflary, because it exceeded the permissible value of $1000 \mathrm{CFU} \cdot 100 \mathrm{~cm}^{-3}$; others can be seen as waters of excellent quality as Escherichia coli generally did not exceeded 200 CFU $\cdot 100 \mathrm{~cm}^{-3}$ (Rozporządzenie Ministra Zdrowia z 8 kwietnia 2011 r.). Surprising may seem high microbiological contamination of cold flowing waters of the Biały Dunajec, however, the impact on it could have the fact that the areas are more urbanized and many households still do not drain sewage into the treatment which may adversely affect the condition of the surrounding watercourses.

Water as an element of the environment is probably the most exposed to chemical and bacteriological contamination. Rivers and water reservoirs have been used as receivers of wastewater for years, which resulted in the degradation of many of them. The appearance or constant presence of pathogenic microorganisms in the water poses a risk of occurrence and spread of infectious diseases (Michałkiewicz and Mądrecka 2009). Although progress in water and wastewater management has eliminated epidemics on a large scale, however not everywhere has it solved the problem of effective wastewater treatment (Langergraber and Muellegger 2005; Smyłła, http://www.ietu.katowice.pl/wpr/Aktualnosci/Czestochowa/Referaty/). In 2014, the National Institute of Hygiene, one of whose goals is to assess the health 
situation of the population in Poland, recorded 11344 bacterial intestinal infections in our country (Materiały Narodowego Instytutu Zdrowia Publicznego, www.pzh.gov.pl) and the cause of many of them was bacteriologically contaminated water.

Table 2. The mean number of Escherichia coli in tested water samples

Tabela 2. Liczebność Escherichia coli w badanych próbkach wody

\begin{tabular}{lc}
\hline $\begin{array}{l}\text { Sampling point } \\
\text { Punkt pobrania }\end{array}$ & $\begin{array}{c}\text { Number of }- \text { Liczebność E. coli } \\
{\left[\mathrm{CFU} \cdot 100 \mathrm{~cm}^{-3}\right]}\end{array}$ \\
\hline 1. Czarny Dunajec - Witów & 27 \\
\hline 2. Czarny Dunajec - Ludźmierz & 72 \\
\hline 3. Biały Dunajec - Poronin & 1860 \\
\hline 4. Biały Dunajec - Szaflary & 1040 \\
\hline 5. Dunajec - Krościenko & 203 \\
\hline 6. Przylasek Rusiecki - Kraków & 2 \\
\hline 7. Bagry - Kraków & 9 \\
\hline 8. Zakrzówek - Kraków & 0 \\
\hline 9. Na Piaskach - Kryspinów & 60 \\
\hline 10. Reservoir Budzyński - Kryspinów & 0 \\
\hline
\end{tabular}

Bacteriological contamination of waters is not just a local problem of southern Poland, but according to research published in the literature, this is a problem on a global scale. Analyzing the results obtained during this study, it can be stated that the risks arising from the presence of drug-resistant bacteria in the tested waters is relatively low comparing with the data forwarded by other researchers, mainly outside of Poland, because among the tested strains rare occurrence of resistant bacteria was detected, among which resistance to one antibiotic dominated, however almost $80 \%$ of the isolates were sensitive to all of the tested substances (Fig. 1).

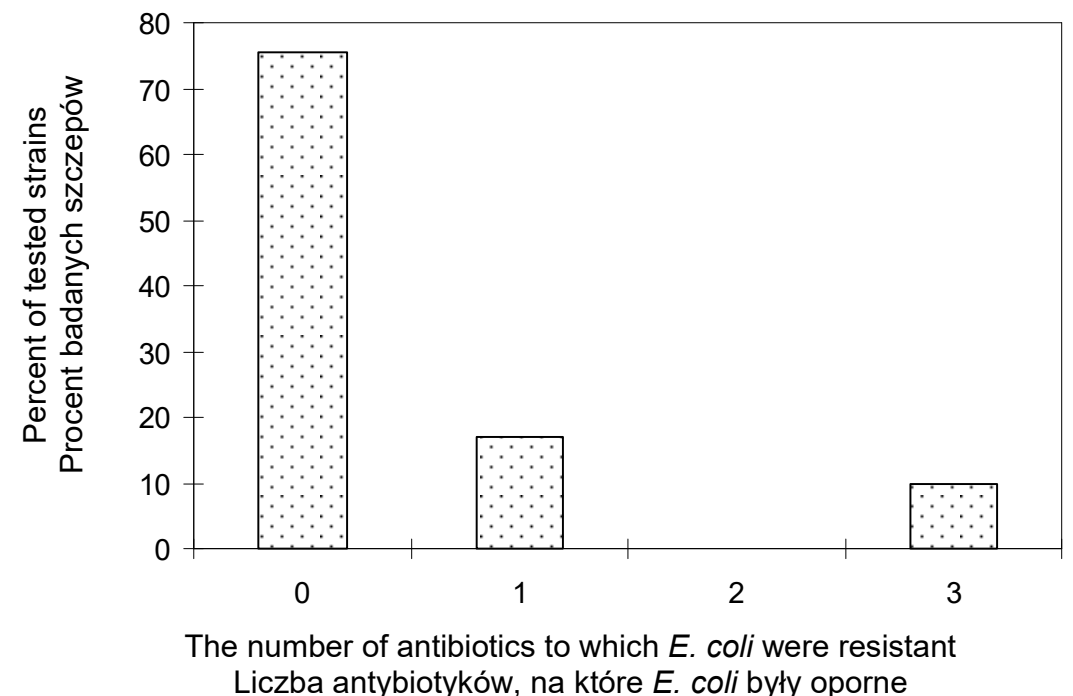

Fig. 1. Percentage of $E$. coli strains resistant on different number of antibiotics

Ryc. 1. Odsetek szczepów E. coli opornych na różną liczbę antybiotyków 
However, in the studied samples the presence of strains resistant to ticarcillin, sulfamethoxazole/trimethoprim, tetracycline was revealed, as well as single isolates not sensitive to amikacin, ampicillin, aztreonam, cefuroxyme, nitrofurantoin, norfloxacin, ofloxacin, The number of resistant strains did not exceed $15 \%$ (Table 3).

Table 3. Percentage of strains resistant on tested antibiotics and its origin

Tabela 3. Odsetek szczepów opornych na poszczególne antybiotyki i ich pochodzenie

\begin{tabular}{lcl}
\hline $\begin{array}{l}\text { Antibiotics* } \\
\text { Antybiotyki }\end{array}$ & $\begin{array}{c}\text { Resistant strains } \\
\text { Szczepy oporne [\%] }\end{array}$ & \multicolumn{1}{c}{$\begin{array}{c}\text { Origin of resistant strains } \\
\text { Pochodzenie opornych szczepów }\end{array}$} \\
\hline Amikacin AN & 2.44 & Kryspinów - Na Piaskach \\
\hline Ampicillin AM & 2.44 & Dunajec - Krościenko \\
\hline Aztreonam ATM & 2.44 & Kryspinów - Na Piaskach \\
\hline Cefuroxyme CXM & 2.44 & Kryspinów - Na Piaskach \\
\hline Nitrofurantoin F/M & 2.44 & Biały Dunajec - Szaflary \\
\hline Norfloxacin NOR & 2.44 & Kryspinów - Na Piaskach \\
\hline Ofloxacin OFX & 2.44 & Kryspinów - Na Piaskach \\
\hline Tetracycline TE & 4.88 & Kryspinów - Na Piaskach $(2.44 \%)$ \\
\hline & & Czarny Dunajec - Witów $(2.44 \%)$ \\
Ticarcillin TIC & 14.64 & Kryspinów - Na Piaskach $(7,32 \%)$ \\
& & Dunajec - Krościenko $(2.44 \%)$ \\
& & Czarny Dunajec - Witów $(2.44 \%)$ \\
Sulfamethoxazole/ & Biały Dunajec - Szaflary $(2.44 \%)$ \\
Trimethoprim SXT & 7.32 & Czarny Dunajec - Witów $(4.88 \%)$ \\
\hline
\end{tabular}

*The table does not include antibiotics that inhibit the growth of all tested strains $-\mathrm{W}$ tabeli nie uwzględniono antybiotyków, które hamują wzrost badanych szczepów.

In comparison, in the rivers of the United States (Ash and Iverson 2002) the largest number of the tested bacteria showed resistance to trimetoprim-sulfmetaksazol (about 63\%) and tetracycline $27 \%$. Da Costa et al. (2008) found that many of the tested strains showed resistance to ampicillin (about 57\%), tetracycline (81\%) and trimetoprim-sulfmetaksazol (about 48\%). Based on studies of water within Ojcowski National Park (streams and springs) Chmiel (2013) found that, among the tested strains of E. coli, 19\% were resistant to three or more antibiotics. Bartosiewicz et al. (2014) conducted a study whose purpose was to analyze resistance to selected antibiotics Escherichia coli isolated from streams within the city of Sopot. Srains isolated by them showed a very diverse level of resistance, but the greatest resistance was observed to gentamicin (approx. 90\% of all tested strains). Based on the results and the literature data, it can be seen that coliforms were mostly resistant to antibiotics normally used in the treatment of bacterial infections. Such an image of drug resistance can attest to the fact that the source of these bacteria are people or livestock, which had or have contact with antibiotics. There is also a possibility that the presence of antibiotics in water is responsible for the modification of genes, including those responsible for resistance to these substances (Matejczyk et al. 2015).

Gram-negative bacteria are a common causes of community- and nosocomial-acquired infections and antimicrobial resistance is rapidly increasing among this bacteria (Oliphant and Eroschenko 2015). The problem of increasing resistance among diverse groups of bacteria is mainly caused by the overuse of antibiotics. Increasingly, there are strains which are resistant to most of $\beta$-lactam antibiotics - means ESBL. The phenomenon of spreading 
of these strains is due to a very intensive use of antibiotics, leading to the selection of newly acquired resistance mechanisms. These include the majority of $\beta$-lactams at the same time (Baraniak 2011). Fortunately, among the tested isolates, the presence of ESBL bacteria was not confirmed. To stop the spread of resistance among microorganisms we must first of all, avoid using antibiotics randomly and use mainly antibiotics with a narrow spectrum of action.

\section{CONCLUSIONS}

1. Water reservoirs in Kraków and Kryspinów may be used for bathing, because the number of Escherichia coli should not exceed the permissible standards, but the Biały Dunajec river pollution makes it unsuitable for recreational purposes.

2. Resistant strains were isolated mainly in one recreational reservoir Kryspinów - Na Piaskach, but they were also present in the waters of the Dunajec river.

3. $25 \%$ of analyzed strains were resistant to at least one of the tested antibiotics, but none of the studied strains of Escherichia coli produced ESBL.

4. Of the surveyed waters were no isolated multidrug resistant $E$. coli strains.

5. Most isolates were resistant to ticarcillin, sulfamethoxazole/trimethoprim and tetracycline.

\section{REFERENCES}

Ash R.J., Iverson J.L. 2002. Antibiotic and disinfectant resistant bacteria in rivers of the United States. Emerg. Infect. Dis. 8 (7), 713-716.

Baraniak A. 2011. Mechanizmy oporności bakterii na antybiotyki $\beta$-laktamowe [Mechanisms of bacterial resistance to $\beta$-lactam antibiotics]. Biul. Narod. Prog. Ochr. Antybiot. 1/2, http://www.antybiotyki.edu.pl/ pdf/biuletyn/. [in Polish]

Bartosiewicz M., Michalska M., Cieszyńska M. 2014. Antybiotykooporność bakterii heterotroficznych jako skutek zanieczyszczenia środowiska [Antibiotic resistance of heterotrophic bacteria as a result of environmental pollution]. Med. Środ. 17(4), 38-46. [in Polish]

Breakpoints tables for interpretation of MICs and zones diameters. Version 5.0. European Committee on Antimicrobial Susceptibility Testing. 2015, http://www.eucast.org/clinical_breakpoints/, access: September 30, 2016.

Brochier V., Gourlan P., Kallassy M., Poitrenaud M., Houot S. 2012. Occurrence of pathogens in soils and plants in a long-term field study regularly amended with different composts and manure. Agr. Ecosyst. Environ. 160, 91-98.

Chmiel M. 2013. Charakterystyka mikrobiologiczna i ocena sanitarna środowiska naturalnego Ojcowskiego Parku Narodowego ze szczególnym uwzględnieniem antropopresji. Kraków, Wydaw. UR Krak., 200. [in Polish]

Da Costa P.M., Vaz-Pires P., Bernardo F. 2008. Antimicrobial resistance in Escherichia coli isolated in wastewater and sludge from poultry slaughterhouse wastewater. J. Environ. Health. 70(7), 40-45.

Estrada I.B., Aller A., Aller F., Gomez X., Moran A. 2004. The survival of Escherichia coli, faecal coliforms and Enterobacteriaceae in general in soil treated with sludge from wastewater treatment plants. Biores. Technol. 93, 191-198.

Gniadkowski M. 2008. Evolution of extended-spectrum $\beta$-lactamases (ESBLs) by mutation. Clin. Microbiol. Infect. 14 (Suppl. 1), 11-32.

Gniadkowski M., Żabicka D., Hryniewicz W. 2009. Rekomendacje doboru testów do oznaczania wrażliwości bakterii na antybiotyki i chemioterapeutyki 2009. Oznaczanie pałeczek Gram-ujemnych, http://www.korld.edu.pl/pdf/02-Rek2009-Paleczki_z_rodziny_Enterobacteriaceae.pdf, access: September 30, 2016. [in Polish] 
Grisey E., Belle E., Dat J., Muddry J., Aleya L. 2010. Survival of pathogenic and indicator organisms in groundwater and landfill leachate through coupling bacterial enumeration with tracer tests. Desalination 261, 1-2, 162-168.

Gutry-Korycka M., Sadurski A., Kundzewicz Z.W., Pociask-Karteczka J., Skrzypczak L. 2014. Zasoby wodne a ich wykorzystanie [Water resources and their use]. Nauka 1, 77-98. [in Polish]

Jarząb A., Górska-Frączek S., Rybka J., Witkowska D. 2011. Zakażenia pałeczkami jelitowymi diagnostyka, oporność na antybiotyki i profilaktyka [Coliforms intestinal infections - diagnosis, antibiotic resistance and prevention]. Post. Hig. Med. Dośw. 65, 55-72. [in Polish]

Kayser F.H., Bienz K.A., Eckert J., Zinkernagel R.M. 2007. Mikrobiologia lekarska. Warszawa, PZWL, 628.

Langergraber G., Muellegger E. 2005. Ecological sanitation - a way to solve global sanitation problems? Eviron. Int. 31, 433-444.

Libudzisz Z., Kowal K. 2000. Mikrobiologia techniczna. T. 1. Łódź, PŁódz., 442. [in Polish]

Mały Rocznik Statystyczny. 2015. Warszawa, GUS. [in Polish]

Martínez-Martínez L. 2008. Extended-spectrum $\beta$-lactamases and the permeability barrier. Clin. Microbiol. Infect. 14(Suppl. 1), 82-89.

Matejczyk M., Rosochacki S.J., Jabłonowski K. 2015. Use of Escherichia coli K-12 strain with gfp reporter gene for screening of cefuroxime and metronoidazole residues in surface water. J. Ecol. Eng. 16(3), 77-82.

Materiały Narodowego Instytutu Zdrowia Publicznego, www.pzh.gov.pl, access: September 30, 2016.

Michałkiewicz M., Mądrecka B. 2009. Problematyka bakteriologicznego skażenia wód [Problems of bacteriological contamination of water]. Technol. Wody 2, 14-19. [in Polish]

Nikonorow E., Baraniak A., Gniadkowski M. 2013. Oporność bakterii z rodziny Enterobacteriaceae na antybiotyki $\beta$-laktamowe wynikająca $z$ wytwarzania $\beta$-laktamaz [The resistance of Enterobacteriaceae on the $\beta$-lactam antibiotic resulting from the production of $\beta$-lactamases]. Post. Mikrobiol. 52(3), 261-271. [in Polish]

Oliphant M.C., Eroschenko K. 2015. Antibiotic resistance. Part 2. Gram-negative pathogens. J. Nurse Pract. 11(1), 79-86 .

PN-EN ISO 19458 : 2007. Jakość wody. Pobieranie próbek do analiz mikrobiologicznych. [in Polish]

PN-EN ISO 9308-1 : 2014-12. Water quality. Enumeration of Escherichia coli and coliform bacteria. Part 1. Membrane filtration method for waters with low bacterial background flora.

Rompré A., Servais P., Baudart J., Roubin M.R. de, Laurent P. 2002. Detection and enumeration of coliforms in drinking water: current methods and emerging approaches. J. Microbiol. Meth. 49, 31-54.

Rozporządzenie Ministra Zdrowia z dnia 8 kwietnia 2011 r. w sprawie prowadzenia nadzoru nad jakością wody w kąpielisku i miejscu wykorzystywanym do kąpieli. DzU z 2011 r., nr 86, poz. 478). [in Polish]

Smyłła A. 2012. Zagrożenia bakteryjne wód powierzchniowych, http://www.ietu.katowice.pl/wpr/ /Aktualnosci//Czestochowa/Referaty/Smylla.pdf, access: September 30, 2016. [in Polish]

Stevens M., Ashbolt N., Cunliffe D. 2003. Review of coliforms, as microbial indicators of drinking water quality. National Health and Medical Research Council, Australian Government, http://www.nhmrc.gov.au/_files_nhmrc/publications/attachments/eh32.pdf, access: September 30, 2016.

Topp E., Welsh M., Tien Y-C., Dang A., Lazarovits G., Conn K., Zhu H. 2003. Strain-dependent variability in growth and survival of Escherichia coli in agricultural soil. FEMS Microbiol. Ecol. 44(3), 303-308.

Van Elsas J.D., Semenov A.V., Costa R., Trevors J.T. 2011. Survival of Escherichia coli in the environment: fundamental and public health aspects. The ISME J. 5, 173-183. 
Abstract. The presence of multi-drug resistant bacteria is no longer only a clinical problem because increasingly, during the microbiological water and soil analysis, the antibiotic resistant bacteria are isolated, which can be a significant health hazard. The aim of this study was the assessment of water sanitary quality and the occurrence of drug resistant strains of Escherichia coli in 10 sampling points located on selected water reservoirs used for recreation on the Dunajec river and reservoirs in Kraków area and Kryspinów. Collected water samples were examined by the membrane filtration technique to assess the number of $E$. coli. Drug resistance was tested using the disc diffusion method as well as the ESBL assay according to KORLD and EUCAST standards. Based on the results, it was found that in two sampling points located on the Biały Dunajec river the population of $E$. coli exceeded standards intended for bathing. Resistant strains were isolated mainly in one bathing place - Kryspinów - Na Piaskach, but they were also present in the waters of the Dunajec river. Most often isolates were resistant only to one of the tested antibiotics, the multidrug resistant $E$. coli were no isolated. The tested strains were mainly resistant to ticarcillin, sulfamethoxazole/trimethoprim and tetracycline. All the tested strains were ESBL negative. 
